\title{
PERBANDINGAN PEMBERIAN IKAN GABUS DAN TELUR AYAM TERHADAP PENYEMBUHAN LUKA PASCA BEDAH POST SECTIO CEASEREA
}

\author{
Dian Zuiatna ${ }^{1}$, Putri Diah Pemiliana ${ }^{2}$, Saskiyanto Manggabarani ${ }^{3}$ \\ ${ }^{1,2}$ Fakultas Farmasi dan Kesehatan, Institut Kesehatan Helvetia Medan, Indonesia \\ ${ }^{3}$ Fakultas Kesehatan Masyarakat, Institut Kesehatan Helvetia Medan, Indonesia \\ dianzuiatna@helvetia.ac.id, putridiah@helvetia.ac.id, zhakymanggabarani@gmail.com
}

\begin{abstract}
According to $\mathrm{WHO}$, the incidence of sectio caesarea in Indonesia is increasing and is around $22.8 \%$ of all deliveries. Delivery by cesarean section of the risk of death is 25 times greater and the risk of infection is 80 times higher than that of vaginal delivery. If the nutrition of the post partum sectio caesarea is not considered, it will affect the wound healing of the post partum sectio caesarean mother which will cause death due to infection. The aim of the study was to test the snakehead fish and chicken eggs in wound healing in post-op sectio caesarean mothers which were applied in health care centers and in patient homes. This type of research is observational with a Quasi experiment design, namely post test only two group design. This research was conducted in Binjai City, a patient who returned home from RSU Artha Medica in 2020. The sample of this study was a post-partum section ceaserea mother who had the same characteristics and the location was in the Binjai City area and had never been given a special provision of snakehead fish and chicken eggs. . The sampling technique was selected by consecutive sampling method consisting of the intervention group. Data were analyzed by univariate and bivariate analysis with the Independent Sample T Test. Based on the results of the study, it was obtained a $p$ value of $0.000<0.05$, which indicated that there was a difference between giving snakehead fish and chicken eggs to the post-sectio ceaserea wound healing process.
\end{abstract}

Keywords: Fish Cork, Chicken Eggs, Post op Sectio Ceacarea Wounds

\section{PENDAHULUAN}

WHO mengeluarkan peringatan akan tingginya angka kejadian sectio cesaerea di seluruh dunia sebanyak $22,5 \%$. Standar rata- rata sectio cesaerea disebuah negara adalah sekitar $10-25 \%$ per 1000 kelahiran di dunia, rumah sakit pemerintah rata- rata $11 \%$ sementara dirumah sakit swasta bisa lebih dari 30\% (FAO and UNICEF, 2018)

Menurut WHO rata-rata sectio caesarea di di America Serikta meningkat hingga 29,1\%, di Inggris dan Wales juga telah mencapai $21,4 \%$, meningkat 5 kali lipat sejak tahun 2010. Selain itu sectio caesarea di Kanada adalah 22,5\%. Data tersebut menunjukkan bahwa secara global, khusus-nya di negaranegara maju, bahwa angka tindakan persalinan melalui Sectio Caesarea terbilang tinggi. Pada tahun 20-an permintaan Sectio Caesarea 
adalah sebesar 5\%, kini lebih dari 50\% ibu hamil menginginkan operasi Sectio Caesarea (Ayuningtyas dkk, 2018). Sedangkan untuk Indonesia angka kejadian sectio caesarea di Indonesia menurut data survei nasional pada tahun 2018 adalah 871.000 dari 3.401 .000 persalinan atau sekitar $19.6 \%$ dari seluruh persalinan (Kemenkes RI, 2019).

Sectio caesarea merupakan jenis persalinan dengan cara pembedahan melalui insisi pada dinding abdomen (laparatomi) dan dinding uterus (histerotomi) yang bertujuan untuk melahirkan Bayi (Anggrahini and Rahayuningsih 2016). Kebutuhan paling utama yang harus dipenuhi oleh ibu post partum dengan luka sectio cesarea adalah nutrisi yang baik untuk sistem imun dan penyembuhan luka. Hal ini dikarenakan ada beberapa zat gizi yang sangat diperlukan untuk mendukung sistem imun tubuh dan berperan penting dalam proses penyembuhan luka (NAESEE, Winarsih Nur Ambarwati, and Suryandari, 2015). Persalinan dengan sectio caesarea berisiko kematian 25 kali lebih besar dan berisiko infeksi 80 kali lebih tinggi di banding persalinan pervaginam. Pada proses section ceaserea, jelaslah pasien mengalami luka dari hasil pembedahan (Yanti, 2018).

Setelah pembedahan, termasuk bedah sectio caesarea yang sering terjadi kondisi demam yang meningkatkan kebutuhan energi, dan luka pendarahan yang dapat meningkatkan kebutuhan protein, zat besi, dan vitamin C. Selain itu, sering terjadi peningkatan ekskresi nitrogen dan natrium yang dapat berlangsung selama 5-7 hari atau lebih pascabedah dan peningkatan ekskresi kalsium setelah dilakukannya operasi besar, trauma kerangka tubuh, atau setelah lama bergerak (imobilisasi) (Almatsier, 2010). Keadaan ini mengharuskan perlunya perhatian terhadap pemberian diet kepada wanita yang merupakan pasien pascabedah sectio caesarea. Kebutuhan paling utama yang harus dipenuhi oleh ibu post partum dengan luka sectio cesarea adalah asupan zat gizi yang baik untuk sistem imun dan penyembuhan luka. Hal ini dikarenakan ada beberapa zat gizi yang sangat diperlukan untuk mendukung sistem imun tubuh dan berperan penting dalam proses penyembuhan luka (Hanifah, 2009) (Per-angin, Isnaniah, and Rizani, 2014).

Gangguan nutrisi terutama kurangnya asupan protein pada pasien post section ceasarea merupakan masalah yang sangat sering muncul, baik pasien yang dijumpai dirumah sakit maupun yang menjalani rawat jalan. Diit tinggi protein pada post sectio cesearea merupakan faktor yang dapat mempengaruhi proses penyembuhan luka (Sumanto, 2016).

Tetapi masih banyak sekali anggapan masyarakat serta pasien yang 
mengalami pembedahan kalau makan makanan yang mengandung protein seperti telur, ikan, daging luka jahitan akan menjadi gatal dan luka lama sembuhnya. Pemberian nutrisi itu terkait dengan jenis makanan yang dimakan, frekuensi, dan jadwal pemberian makanan (Susetyowati, Ija, and Makhmudi, 2010). Seperti pnelitian yang dilakukan oleh Hidayati dengan judul Hubungan perilaku pantang makanan dengan lamapenyembuhan luka perineum pada ibu nifas Di Kecamatan Srengat Kabupaten Blitar. Berdasarkan hasil pnelitian yaitu ada hubungan yang signifikan antara perilaku pantang makanan dengan lama penyembuhan luka perineum pada ibu nifas di Kecamatan Srengat Kabupaten Blitar (Hartiningtiyaswati, 2010).

Berdasarkan penelitian Ficus, 2014 ada pengaruh diet protein tinggi dengan penyembuhan luka post SC, namun penelitian berbeda dalam intervensi karena penelitian ini melihat pengaruh dari 2 diit protein tinggi (Feriyanto, 2014).

Data RSU Artha Medica Kota Binjai tahun 2018 pasien section ceaserea sebanyak 647 orang. Berdasarkan hal tersebut rumusan masalah dapat dikemukakan sebagai berikut :" Efektivitas diit tinggi protein terhadap proses penyembuhan luka pasca bedah post sectio ceaserea di Kota Binjai?. Berdasarkan hasil wawancara di Kota Binjai dari 5 ibu post op sectio seacarea, 2 orang mengatakan lukanya mengalami infeksi dan lama sembuh, untuk konsumsi makanan setiap harinya tidak melibatkan tinggi protein, sedangkan 3 orang lainnya mengatakan lukanya tidk bernanah namun lama sembuhnya sesekali rutin mengkonsumsi ikan gabus dan telur. Tujuan Penelitian untuk mengetahui pengaruh konsumsi diit protein tinggi terhadap penyembuhan luka pasca bedah post sectio ceaserea.

\section{METODE}

Tahapan penelitian meliputi persiapan dan pengurusan ijin penelitian, pendistribusian penyuratan, pendataan awal (melihat luka bekas operasi Sectio caesaria), pelaksanaan intervensi, controling, monitoring dan evaluasi. Rancangan penelitian ini menggunakan Quasi experiment yaitu post test two grup design. Kelompok perlakukan diberikan ikan gabus dan telur ayam selama 24 hari. Pemeriksaan luka dilakukan pada bagian luka Sectio caesaria setiap 3 hari sekali selama 24 hari. Populasi dalam penelitian ini adalah seluruh pasien post section ceaserea di Kota Binjai yang pulang dari RSU Artha Medica. Sampling pada penelitian ini menggunakan metode 
Consecutive sampling yaitu setiap responden yang memenuhi kriteria penelitian dimasukkan dalam penelitian sampai kurun waktu tertentu, sehingga jumlah pasien yang diperlukan terpenuhi yaitu sebanyak 30 orang selama 4 bulan dari Maret sampai Juni 2020 terdiri dari 2 kelompok (kelompok intervensi 1 yaitu ikan gabus 15 orang dan kelompok 2 hanya telur ayam 15 orang) pasien post op sectio Ceaserea hari ke-1, kriteri inklusi tidak memiliki riwayat penyakit DM (Diabetes Melitus), Usia 20-35 tahun, jika pasien tidak suka ikan maka akan masuk ke kelompok intervensi menggunakan telur ayam, selain itu pasien bersedia menjadi responden. Instrument yang digunakan dalam penelitian ini adalah sebagai berikut: dengan mengobservasi luka Sectio caesaria. Pemeriksaan luka bekas Sectio caesarea dilakukan dengan observasi dengan pemeriksaan fisik setelah itu melihat luka dengan obeservasi menggunakan kuesioner yang terdiri dari 20 item pernyataan lembar check. Tujuan untuk mendeskripsikan penyembuhan luka post op Sectio caesaria. Kemudian memberikan konsumsi pada kelompok intervensi 1 Diit tinggi protein berupa telur ayam rebus sebanyak 70 gram yang diberikan pagi hari, 70 gram pada siang dan 60 gram pada malam hari selama 24 hari. Pada kelompok intervensi 2 hanyak diberikan ikan gabus sebanyak 70 gram pada pagi hari, 70 gram pada siang hari dan 70 gram pada malam hari dalam bentuk steam selama 24 hari yang masakan dan diantar kerumah pasien post SC selama 3 hari sekali. Data sekunder mencakup gambaran umum lokasi, dan serta pendukung lainnya termasuk jumlah pasien post op Sectio caesaria yang diperoleh dari data RSU Artha Medica Data Primer diperoleh dengan wawancara langsung dengan menggunakan kuesioner dan observasi. Penilaian luka section ceaserea berdasarkan proses fisiologis penyembuhan yang terdiri dari 4 fase yaitu infalamasi, destruksi, proliferasi dan maturasi. Analisis yang digunakan untuk menguji kemaknaan pengaruh dan uji beda mean variabel penelitian antara intervensi kelompok ikan gabus dan kelompok telur ayam, jika sebaran data berdistribusi normal maka digunakan uji parametric analisis of varian dan Independent Sample T Test, dengan tingkat kepercayaan 95\% dan signifikansi yang digunakan $\mathrm{p}<0,05$. Penelitian ini sudah mendapatkan persetujuan kelayakan untuk diteliti dari kode etik USU. 


\section{HASIL DAN PEMBAHASAN}

\section{Karakteristik Responden}

Berdasarkan Karakteristik

Responden umur 20-35 tahun sebanyak 10 orang $(33, \%)$, umur 26-30 tahun sebanyak 12 orang $(40,0 \%)$, berumur $31-35$ tahun sebanyak 8 orang $(26,7 \%)$. Sedangkan

$0 \%)$. pendidikan peguru tinggi sebanyak 11 orang (36,7\%), SMA sebanyak 17 orang (56,4\%), dan SMP sebanyak 2 orang $(6,7 \%)$. Berdasarkan paritas primipara sebanyak 8 orang (26.7\%), scundipara sebanyak 9 orang $(30,0 \%)$, multipara sebanyak 10 orang $(33,3 \%)$, grandemultipara sebanyak 3 orang (10,

Tabel 1. Karakteristik Responden

\begin{tabular}{lcc}
\hline Karakteristik Responden & Frekuensi & Persentase \\
\hline Umur & 10 & 33,3 \\
20-25 tahun & 12 & 40,0 \\
26-30 tahun & 8 & 26,7 \\
31-35 Tahun & & \\
\hline Pendidikan & 11 & \\
PT & 17 & 36,7 \\
SMA & 2 & 56,4 \\
SMP & & 6,7 \\
& & \\
Paritas & 8 & 26,7 \\
Primipara & 9 & 30,0 \\
Scundipara & 10 & 33,3 \\
Multipara & 3 & 10,0 \\
Grandemultipara & & \\
\hline
\end{tabular}

\section{Bivariat}

Data yang diperoleh merupakan data primer dan berskala numerik, sehingga dilakukan analisis kuantitatif menggunakan uji statistik parametrik (Uji $T$ pairet test ). Uji ini dilakukan dengan menggunakan program SPSS 17.0 for Windows.

\section{1) Uji Persyaratan}

Uji Persyaratan sebelum analisis anova dilaksanakan, terlebih dahulu dilakukan uji normalitas data dan uji homogenitas data. Adapun uji normalitas dan homogenitas sebagai berikut

\section{a. Uji Normalitas}

Berdasarkan uji normalitas yang dilakukan pada kelompok ikan yaitu 0,473>0,05 sehingga menunjukan data berdistribusi normal. Kelompok tlur ayam dilakukan uji normalitas dengan nilai $0,208>0.05$ sehingga dapat disimpulkan bahwa data antara ikan gabus dan telur ayam merupakan data berdisribusi normal. 
Tabel 2. Hasil Uji Normalitas Data

\begin{tabular}{lccc}
\hline Kelompok & \multicolumn{3}{c}{ Shapiro-Wilk } \\
\cline { 2 - 4 } & Statistik & df & Sig. \\
\hline Ikan Gabus & 0.947 & 15 & 0.473 \\
Telur Ayam & 0,922 & 15 & 0,208 \\
\hline
\end{tabular}

Sumber : Data Primer, 2020

\section{b. Uji Homogenitas}

Berdasarkan hasil uji homogenitas

yang dilakukan dengan uji anova

diperloh nilai hitung $0.688>0.05$

Tabel 3. Hasil Uji Homogenitas Data

\begin{tabular}{cccc}
\hline Levene Statistic & Df1 & Df2 & Sig. \\
\hline 1,88 & 1 & 28 & 0,668 \\
\hline Sumber : Data Primer, 2020 & & &
\end{tabular}

3. Uji Statistik

Hasil tabel 5. rata-rata penyembuhan luka post SC sebesar 13,60 dan standar deviasi 1,183 dengan intervensi 1 ikan gabus, rata-rata penyembuhan pada luka SC pada kelompok intervensi 2 telur ayam sebesar 9,00 dengan standar deviasi 1,309. Hasil uji statistik dengan independent sample $T$ test diperoleh nilai $\mathrm{p} 0,000<0,05$ yang menunjukkan ada perbedaan yang signifikan terhadap penyembuhan luka SC antara ikan gabus dengan telur ayam.

Pada penelitian ini selama mengalkukan penelitian terdapat 4 fase yang terjadi pada luka responden yaitu Fase inflamasi merupakan reaksi tubuh terhadap luka yang dimulai setelah beberapa menit dan berlangsung sekitar 3 hari setelah cedera. Pada fase ini terjadi pemberhentian perdarahan dan sehingga hal ini dapat diimpulkan bahwa data homogen atau sama. membersihkan area luka dari benda asing, sel-sel mati dan bakteri untuk mempersiapkan dimulainya proses penyembuhan. Setelah terjadinya luka, pembuluh darah yang putus mengalami konstriksi dan retraksi disertai reaksi hemostasis karena agregasi trombosit yang bersama jala fibrin membekukan darah. Fase proliferasi ditandai dengan munculnya pembuluh darah baru sebagai hasil rekonstruksi, fase proliferasi terjadi dalam waktu 3-24 hari.

Fase destruksi merupakan pembersihan terhadap jaringan mati yang mengalami devitalisas dan bakteri oleh polimog dimana polimogf menghancurkan bakteri.

Fase maturasi merupakan tahap akhir proses penyembuhan luka. Dapat memerlukan waktu lebih dari 1 tahun, bergantung pada kedalaman dan 
keluasan luka. Tujuan dari fase maturasi adalah menyempurnakan jaringan yang baru terbentuk menjadi jaringan yang kuat. Serat fibrin dari kolagen bertambah banyak untuk memperkuat jaringan parut.

Proses sintesis, degradasi dan remodeling kolagen pada fase proliferasi dan maturasi penyembuhan luka ternyata tak boleh luput dari perhatian. Proses tersebut mempengaruhi kualitas akhir penyembuhan luka dengan menampilkan berbagai tipe jaringan parut. Untuk mencapai penyembuhan yang optimal diperlukan keseimbangan antara produksi kolagen dengan yang dipecah. Luka dikatakan sembuh jika terjadi kontinuitas lapisan kulit dan kekuatan jaringan parut mampu atau tidak mengganggu aktifitas normal. Meskipun proses penyembuhan luka sama bagi setiap penderita, namun outcome atau hasil yang dicapai tergantung pada kondisi biologis masing-masing individu, lokasi serta luasnya luka, seperti kekurangan nutrisi, infeksi, perawatan luka yang benar dan genetik (Wijaya and Kep, 2018).

Tabel 4. Hasil Uji Hipotesis dengan Independent Sample T Test

\begin{tabular}{lcccc}
\hline Kelompok & Mean & SD & SE & P Value \\
\hline Ikan Gabus & 13,60 & 1,183 & 0,306 & \multirow{2}{*}{0,000} \\
\cline { 1 - 4 } Telur Ayam & 9,00 & 1,309 & 0,338 & \\
\hline Sunn : Dat Pring
\end{tabular}

Sumber : Data Primer, 2020

Berdasarkan hasil penelitian diketahui rata-rata penyembuhan luka post SC sebesar 13,60 dan standar deviasi 1,183 dengan intervensi ikan gabus dan telur ayam, rata-rata penyembuhan pada luka SC pada kelompok intervensi telur ayam sebesar 9,00 dengan standar deviasi 1,309. Hasil uji statistik dengan independent sample $T$ test diperoleh nilai $\mathrm{p} 0,000<0,05$ yang menunjukkan ada perbedaan yang signifikan terhadap penyembuhan luka ibu post partum pasca SC dengan pemberian ikan gabus dan telur ayam.
Hasil penelitian ini sejalan dengan penelitian Nurhikmah (2020) Pengaruh Pemberian Ikan Gabus Terhadap Penyembuhan Luka Sectio Caesarea Pada Ibu Pospartum Di Wilayah Kerja Puskesmas Ciasem Subang Tahun 2020. Hasil penelitian menunjukkan terdapat pengaruh yang signifikan $(p<0,05)$ pemberian ikan gabus rebus terhadap penyembuhan luka sectio caesarea antara kelompok perlakuan dengan kelompok kontrol di Wilayah Kerja Puskesmas Ciasem Tahun 2020. 
Penyembuhan luka yang ideal adalah kembali normalnya struktur, fungsi, dan anatomi kulit. Batas waktu penyembuhan luka ditentukan oleh tipe luka dan lingkungan instrinsik maupun ekstrinsik. Jahitan biasanya diangkat pada saat sudah terlihat adanya tensile strength yang mendekatkan tepi luka. Pengangkatan jahitan ini tergantung usia, status nutrisi, dan lokasi luka. Kolagen ini muncul pada hari ke-5 sampai dengan ke-7 post operasi. Bila lebih dari tujuh hari berarti terjadi perlambatan sintesiskolagen yang berarti penyembuhan luka lambat (Wahyudi and Wahid, 2016).

Proses penyembuhan luka banyak dipengaruhi oleh nutrisi, daya tahan tubuh dan pemberian suplemen. Nutrisi yang dibutuhkan untuk penyembuhan luka yaitu mengkonsumsi makanan yang serat akan protein. Protein didapatkan pada makanan, daging dan ikan. Semua jenis ikan adalah sumber protein yang sangat baik. Ikan gabus diketahui sebagai ikan dengan kandungan gizi dan protein yang lebih banyak dari ikan jenis lain seperti ikan bandeng Selain ikan bandeng, keunggulan ikan gabus mempunyai protein yang tinggi, kadar protein per 100 gram ikan gabus setara dengan ikan bandeng (Munandar, 2018).

Ikan gabus merupakan salah satu jenisa ikan yang banyak digunakan oleh masyarakat untuk penyembuhan luka terutama luka pasca operasi, luka bakar dan setelah persalinan karena kandungan utama dalam ikan gabus adalah albumin yang cukup tinggi yang merupakan protein terbanyak dalam plasma sekitar 60\% dari total plasma dengan nilai normal 3,3-5,5 g/dl. (Eddy Suprayitno 2003) Ikan gabus 100 gram mengandung 25,2 gram protein. Bandingkan kandungan protein per 100 gram daging ayam yang hanya mengandung protein 18,2 gram, daging sapi hanya mengandung protein 18,8 gram, telur hanya mengandung protein 12,8 gram. Karenanyalah kandungan protein yang tinggi ini menguntungkan, karena akan banyak membantu dalam proses pembentukan otot pada tubuh manusia. Sehingga protein ikan gabus merupakan faktor proses percepatan penyembuhan luka jahitan pada ibu post op sectio seacarea (E Suprayitno, 2003).

Penelitian Yanti mengungkap pemanfaatan ekstrak ikan gabus sebagai pengganti serum albumin

yang biasanya digunakan untuk penyembuhan luka operasi. Untuk pemanfaatan ikan gabus sebagai obat, ikan diambil ekstraknya dengan cara mengukusnya, lalu menampung airnya. Air ekstrak langsung diminumkan terhadap pasien yang baru selesai operasi. Dengan cara itu luka akan sembuh tiga hari lebih 
cepat dibanding bila diberi serum albumin (Yanti 2018).

Protein atau zat putih telur merupakan bahan utama dalam pembentukan sel jaringan yang rusak dan disebut sebagai unsur atau zat pembangun, mengandung protein bermutu tinggi karena terdapat susunan asam amino esensial lengkap sehingga telur dijadikan patokan dalam menentukan mutu protein berbagai bahan pangan. Pemberian putih telur yaitu dengan cara diberikan melalui proses perebusan. Putih telur yang digunakan peneliti ada telur ayam kampung karena kandungan protein pada telur ayam kampung ini lebih tinggi. Putih telur ini aman dikonsumsi oleh ibu nifas yang memiliki luka jahitan operasi karena efek dari protein ini sangat membantu dalam pembentukan kembali sel jaringan yang rusak. Dalam telur rebus mengandung zat kolin yang mempunyai efek memperbaiki sel tubuh yang rusak sehingga jaringan baru dan sehat akan lebih mudah terbentuk menggantikan jaringan yang sudah aus. Karena itu protein disebut sebagai unsur atau zat pembangun. Salah satunya protein yang terdapat pada telur untuk penyembuhan luka pasca operasi caesar, hal itu disebabkan oleh adanya kandungan asam amino yang ada pada telur. Seseorang yang mempunyai luka jahitan sangat membutuhkan asupan protein yang cukup agar luka jahitan cepat kering dan sembuh. Terbukti, komposisi pada putih telur ada sekitar 57\% yang kaya akan protein dibandingkan bagian telur yang lainnya. Lama penyembuhan kulit tiap orang berbeda-beda, karena itu tidak dapat dipastikan penyembuhannya (Eddy Suprayitno, 2003).

Penilaian luka section ceaserea berdasarkan proses fisiologis penyembuhan yang terdiri dari 4 fase yaitu infalamasi, destruksi, proliferasi dan maturasi.

Menurut Asumsi peneliti bahwa penyembuhan luka dengan diit protein tinggi berperan untuk pergantian jaringan seperti dengan pemberian protein putih telur dan ikan gabus, usia, pendidikan, paritas, selain itu menjaga kebersihan dan mencegah terjadinya infeksi sehubungan dengan penyembuhan jaringan. Perlunya nutrisi diet, fenomena yang berkembang dimasyarakat saat ini adalah masih banyaknya mitos dimasyarakat yang mempengaruhi kesehatan pada ibu nifas, terutama pada ibu yang melahirkan dengan cara sectio casarea seperti tidak memperbolehkan mengkonsumsi makanan seperti, telur, daging, udang karena akan memperburuk luka jahitan. Padahal jenis makanan tersebut sangat penting untuk proses penyembuhan luka. 
Pemberian ikan gabus pada kelompok perlakuan dimaksudkan untuk mempercepat penyembuhan luka post sectio caesarea. Karena ikan gabus merupakan salah satu jenis ikan yang kandungan utamanya adalah protein atau albuminnya yang cukup tinggi. Dan pemberian telur ayam pada kelompok perlakukan juga untuk mempercepat penyembuhan luka post sectio caesarea karena telur ayam merupakan protein hewani yang memiliki kandungan adanya beberapa kandungan asam amino yang ada di dalam putih telur dan zat kolin yang mempunyai efek memperbaiki sel tubuh yang rusak sehingga jaringan baru dan sehat akan lebih mudah terbentuk menggantikan jaringan yang sudah aus.

\section{KESIMPULAN DAN SARAN}

Terdapat perbandingan pemberian ikan gabus dan telur ayam terhadap penyembuhan luka pasca bedah Post Sectio Ceaserea dengan hasil uji statistik Independent Sample $\mathrm{T}$ Test dengan nilai sig $0.000<0.05$

Diharapkan pemberian diit dan pemenuhan gizi kepada pasien post sectio ceaserea untuk penyembuhan luka yang baik.

\section{UCAPAN TERIMAKASIH}

Terimakasih

kepada

Kemenristekdikti dan Lldikti Wil 1 yang telah memberikan suport baik maupun materi maupun pengarahan dalam penelitian ini, dan kepada direktur RSU yang telah memberikan ijin dalam penelitian ini.

\section{DAFTAR PUSTAKA}

Anggrahini, Lulia, and Faizah Betty Rahayuningsih. 2016. "Upaya Peningkatan Nutrisi Pada Pasien Post Sectio Caesarea Di RSU Assalam Gemolong."

FAO, IFAD, and UNICEF. 2018. "WFP and WHO. 2017. The State of Food Security and Nutrition in the World 2017. Building Resilience for Peace and Food Security. Rome: FAO."

Feriyanto, Ficus Rica. 2014. "Pengaruh Diet Tinggi Protein Terhadap Penyembuhan Luka Pada Pasien Post Operasi Sectio Sesarea Di Ruang Nifas RSD Balung Jember.” [Skripsi]. Universitas Muhammadiyah Jember.

Hartiningtiyaswati, Setiya. 2010.

"Hubungan Perilaku Pantang

Makanan Dengan Lama

Penyembuhan Luka Perineum

Pada Ibu Nifas Di Kecamatan Srengat Kabupaten Blitar."

Kemenkes RI. 2019. "Data Dan Informasi Profil Kesehatan Indonesia 2018."

Munandar, Imam. 2018. "Kepatuhan 
Perawat Dalam Pelaksanaan

Standar Operasional Prosedur

(SOP) Perawatan Luka Dengan

Kejadian Infeksi Luka Operasi

Post Sectio Caesaria." Jurnal

Ilmiah Ilmu Keperawatan

Indonesia 8(2): 422-28.

NAESEE, NIAINU, S Kep Winarsih

Nur Ambarwati, and Dewi

Suryandari. 2015. "Hubungan

Status Nutrisi Ibu Nifas Dengan

Proses Penyembuhan Luka Post

Operasi Sectio Caesarea Di RSUD

Dr. Moewardi."

Per-angin, Nirwana, Isnaniah Isnaniah,

and Ahmad Rizani. 2014.

"Prosespenyembuhan Luka Post

Operasi Sectio Caesariadi Rsud

Ratu Zalecha Martapura Tahun

2013." Jurnal Skala Kesehatan

$5(1)$.

Sumanto, Joko. 2016. "Hubungan

Antara Asupan Vitamin C Dan

Zinc Dengan Proses Penyembuhan

Luka Pasien Pasca Caesarean

Section Di Instalasi Rawat Jalan Di

Rumah

Sakit

PKU

Muhammadiyah Surakarta."

Suprayitno, E. 2003. "Albumin Ikan

Gabus (Ophiocephalus Striatus)

Sebagai Makanan Fungsional

Mengatasi Gizi Masa Depan.”

Suprayitno, Eddy. 2003. "Penyembuhan

Luka Dengan Ikan Gabus.”

Fakultas Perikanan. Universitas
Brawijaya. Malang.

Susetyowati, Susetyowati, Maya Ija, and Akhmad Makhmudi. 2010. "Status

Gizi Pasien Bedah Mayor

Preoperasi Berpengaruh Terhadap Penyembuhan Luka Dan Lama Rawat Inap Pascaoperasi Di RSUP

Dr Sardjito Yogyakarta." Jurnal Gizi Klinik Indonesia 7(1): 1-7.

Wahyudi, Andri Setiya, and Abd Wahid. 2016. "Ilmu Keperawatan Dasar."

Jakarta: Mitra Wacana Media.

Wijaya, Ners I Made Sukma, and M Kep. 2018. Perawatan Luka Dengan Pendekatan Multidisiplin. Penerbit Andi.

Yanti, Desiari Madi. 2018. "Hubungan Asupan Protein Dengan Penyembuhan Luka Pada Pasien Post OP Sectio Caesarea (SC) Di Rumah Sakit Umum Daerah Pringsewu Lampung Tahun 2016." Jurnal Asuhan Ibu dan Anak 3(2): 1-9. 